\title{
脈瘤性骨囊胞を併発した化骨性線維腫の1例
}

神部芳則・赤坂庸子・古藤茂昭

渡辺是久*・水沼仁孝**

\section{A case of ossifying fibroma with aneurysmal bone cyst formation}

\author{
Yoshinori Jinbu • Yoko AKaSAKa • Shigeaki КотO \\ Yoshihisa Watanabe* $*$ Kimiyoshi Mizunuma**
}

Key words: ossifying fibroma (化骨性線維腫), aneurysmal bone cyst（脈瘤性骨轚胞）

\section{緒言}

化骨性線維腫は, いわゆる顎骨の fibro-osseous-lesion に含まれる病変の1つであるが，午の病態については必 ずしも明確にされていない，今回われわれは，内部に脈 瘤性骨囊胞を合併した化骨性線維腫の1例を経験したの で報告する。

\section{症}

\section{例}

患 者: 37歳 女性.

初 診: 平成元年 8 月日 日。

主 訴：右側上顎臼歯部の腫脹.

既往歴, 家族歴 : 特記事項なし。

現病歴: 平成元年 5 月頃右頓部の腫脹に気づき同時に 右側上顎田歯部に硬い腫瘤を自覚したが痛みがないため 放置していた。最近，しだいに同腫瘤が増大してきたた め 8 月 2 日某歯科医院を受診し, 8 月日日当科を紹介さ れ来院した.

現 症

口腔内所見 : 右側上顎臼歯部に頓側㧍よび口蓋側へ歯

自治医科大学萪科口腔外科学教室

（主任：赤坂庸子教授）

$*$ 神奈川菌科大学口腔病理学教室 （主任：渡辺是久教授）

** 大田原赤十字病院放射線科 （主任：水沼化孝部長）

Jichi Medical School Department of Dentistry and Oral Surgery (Chief: Prof. Yoko Akasaka)

* Kanagawa Dental College Department of Oral Pathology (Chief: Prof. Yoshihisa Watanabe)

** Ootawara Red Cross Hospital Department of Radiology (Chief: Kimiyoshi Mizunuma) 受付日: 平成 3 年11月15日

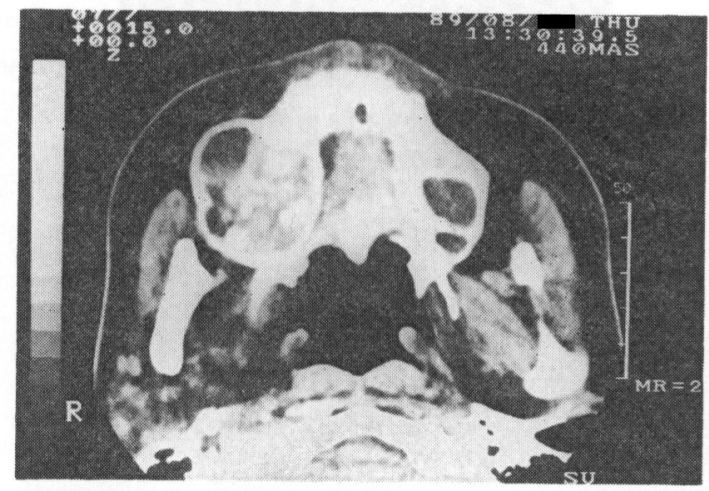

写真 1 CT 像

槽頂から約 $15 \mathrm{~mm}$ の範囲で骨様硬の膨隆を認めた。近 心は $\underline{5}$ の根尖部で遠心は上買結節までの範囲であり， 境界は比較的明膫, 粘膜は正常色を呈し膨隆部に圧痛 は認めなかった。 $\underline{5} \mid$ は動摇度 $\mathrm{M}_{2}$ で 775 は欠損してい た。

$\mathbf{X}$ 線所見 : オルソパントモグラムで 76 部の骨の膨隆 特よび $4 \mid$ 部から上顎結節にいたる 境界明瞭で，一部に X線透過像と不透過像の混在した部分を含をスリガラス 様所見を呈する単胞性の病変を認めた。 CT では頓側お よびロ蓋側への上買骨皮質の著明な膨隆を認め, その内 部は多数の石灰化物を含む軟組織部分と, 囊胞の部分の 2 つの成分から構成されていた（写真1）．右上靧洞は 上方に圧迫されていたが，病変部との間には 1 層の骨を 認め, 上頢洞内には炎症などの異常所見はみられなかっ た.

臨床検查結果 : 特に異常は認められなかった。

臨床診断：上顎良性腫瘍.

処置および経過 : 平成元年12月日日全麻下に腫瘍全摘 出術を施行した。すなわち, 右上罘結節から $\underline{5}$ 遠心に かけて歯槽頂部にまた 3 遠心まで $\underline{54}$ の歯頸部に沿 


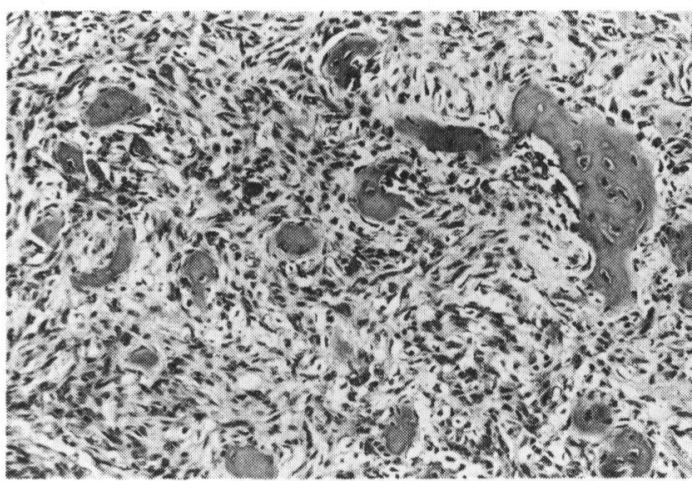

写真 2 軟組織部の病理組織像

って切開を加えて骨膜を剥離， 4 |を抜歯した後，腫瘍 の上縁に沿って上䪽骨頓側およびロ蓋側の骨を削除. 腫 痬を鈍的に剝離し，腫瘍内に進入している大口蓋動脈の 分枝を結禁切断して腫瘍を一塊に摘出した。蓋粘膜に 有頸弁を作成し，頼側粘膜と桻合し，手術を終了した。 術後経過は良好で現在再発はみられない.

摘出物所見：摘出物は約 $42 \times 38 \times 40 \mathrm{~mm}$ で，その割 面は灰白色実質性で辺縁に $10 \times 7 \mathrm{~mm}$ 大の囊胞形成が認 められた。

病理組織学的所見: 石灰化物を含む軟組織部では, 紡 鏵形の線維芽細胞を多数混ずる線維性結合組織と不規則 に散在する骨様硬組織の 形成が認められた (写真 2). 破骨細胞の出現はほとんど観察されず，幼若な骨梁 (woven bone) の形成も認められなかった。

以上の所見から化骨性線維腫と診断した。また鞟胞壁 の構造は線維性組織からなり, 脈瘤性骨囊胞の組織像に 類似する所見であった，囊胞内にはエオジンに淡染する 漿液様物質が認められた（写真了）.

\section{考察}

化骨性線維腫は1927年 Montgomery ${ }^{1)}$ により最初に報 告された疾患であるが, その後症例を重ねるに伴い, 本 疾患を腫瘍性病変と考劣る場合と異形成, 特に単骨性線 維性骨異形成症と同一病変とみる 2 つの考光方が生じて きた ${ }^{2 \sim 4)}$. 本症例の場合, $\mathrm{X}$ 線所見括よび摘出時の所見 から本疾患は良性腫瘍としての発育形態を示していると 考劣られた. 一方, 病理組織学的には, 囊胞の部分と石 灰化物を含さ骨線維性組織からなり, 充実性組織は化骨 性線維腫と線維性骨異形成症の鑑別に関する病理組織学 的診断基準に基づいて化骨性線維腫と診断された ${ }^{4)}$. 囊

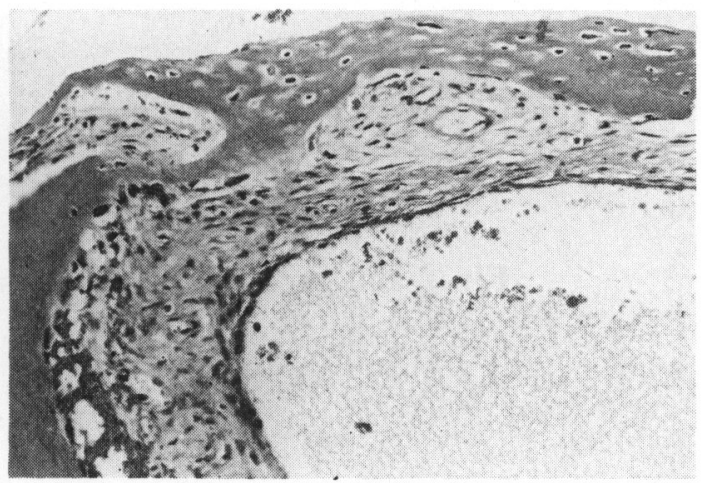

写真 3 囊胞部の病理組織像

胞の部分については, 脈瘤性骨囊胞の組織像にきわめて 類似していた。脈瘤性骨囊胞については成り立ちや本態 については不明であるが，静脈血栓あるいは動静脈瘤 などの局所循環障害が原因で発生すると考えられてい $ろ^{5)}$ ，線維性骨疾患に 合併する場合があり， Struthers ら ${ }^{5)}$ は化骨性線維腫の $4 \%$ に脈瘤性骨囊胞の合併がみら れたと報告して拈り， Eversole ${ }^{6)}$ は 64 例中 3 例に脈瘤性 骨囊胞の合併を報告しているように発生頻度はかなり少 ない，本症例の場合，われわれは臨床所見ならびに病理 学的所見から内部に脈瘤性骨囊胞を合併した化骨性線維 腫と診断した。

\section{引用 文 献}

1) Montogomery, A.H.: Ossifying fibroma of the jaw. Arch Surg 15: 30-44 1927.

2) Waldron, C.A. and Giansanti, J.S.: Benign fibro-osseous lesions of the jaws, A clinicalradiological-histological review of sixty-five cases. Oral Surg 35: 190-201 1973.

3) Slootweg, P.J. and Müller, H.: Differential Diagnosis of Fibro-osseous Jaw Lesions. A Histrogical Investigation on 30 cases. J Cranio Max Fac Surg 18: 210-214 1990.

4) 山本 笔, 茅野照雄: 顎骨のfibro-osseous-lesion 一とくに線維性骨異形成症と化骨性線維腫につ いて一. 口病誌 52: 483-489 1985.

5) Struthers, P.J. and Shear, M.: Aneurysmal bone cyst of the jaw (II). Pathogenesis Int J Oral Surg 13: 92-100 1984.

6) Eversole, L.R., Leider, A.S., et al.: Ossifying fibroma: A clinicopathological study of sixtyfour cases. Oral Surg 60: 505-511 1985. 